\title{
PERENCANAAN GEDUNG SEKOLAH MENENGAH ATAS DENGAN SISTEM PELAT SATU ARAH DAN DUA ARAH
}

\author{
(Plan of Building High School with Oneway Slab and Twoway Slab)
}

\author{
Rizky Iqbal Rahmatullah Saepudin Putra ${ }^{1}$, Cece Suhendi ${ }^{2}$, Paikun ${ }^{3}$ \\ 1,2,3 Universitas Nusa Putra
}

Korespondensi Penulis: Kp. Sawahlega RT.05/RW.01 Desa Mangkalaya Kab. Sukabumi

Email: iqrasaputra19@gmail.com, cece.suhendi@nusaputra.ac.id, paikun@nusaputra.ac.id

Diterima: September 2019; Direvisi (Revised): Desember 2019; Disetujui untuk Dipublikasikan (Accepted): Maret 2020

\begin{abstract}
ABSTRAK
Pelat merupakan salah satu komponen struktur yang memiliki peran penting dalam meningkatkan fungsi kegunaan bangunan. Dalam pelaksanaannya, pelat dapat dibagi menjadi dua yaitu sistem pelat satu arah dan sistem pelat dua arah. Perbedaannya terletak pada asumsi distribusi beban yang disalurkan ke balok. Pada beberapa model bangnunan, terdapat model yang hanya cocok dengan sistem pelat dua arah, begitu pun sebaliknya. Oleh karena itu perlu dilakukan studi perbandingan dilihat dari segi efisiensi biaya dan kebutuhan material. Pengambilan data dilakukan dengan observasi langsung ke lapangan untuk mendapatkan ukuran lahan. Objek penelitian berupa gedung sekolah dua lantai dengan ukuran denah kelas 9x8 meter, dilakukan analisa dengan metode perencanaan elastis. Setiap dimensi komponen struktur dibuat serupa antara sistem pelat satu arah dan dua arah. Hasil penelitian menunjukkan bahwa selisih anggaran biaya antara sistem pelat satu arah dan dua arah senilai $2 \%$, lebih ekonomis sistem pelat dua arah. Perbedaan yang signifikan terletak pada volume beton. Sistem pelat satu arah lebih boros pada balok anak senilai 35\%. Sementara untuk besi tulangan, sistem pelat satu arah $10 \%$ lebih banyak daripada sistem pelat dua arah.
\end{abstract}

Kata kunci: Pelat satu arah, pelat dua arah, struktur lentur.

\section{ABSTRACT}

Slab is one of structure's component which has an important role in improving the function of building use. The implementation can be divided into two models, there are oneway slab and twoway slab. The differences in assuming distribution of load to beam. In some building's model, there are models that only fit by twoway slab, and vice versa. Therefore a comparative study is needed to be done from the aspect of cost efficiency and material requirements. Data retrieval is done by direct observation into the field to obtain the floor plan. Object study is a two stories of school building with floor plan 9x8 meters and done with elastic method. Each dimension of structure's component are same between one way slab and two way slab. The results of this study shows that differences of cost between one way slab and two way slab is 2\%, more efficient two way slab. A significant difference is in volume of concrete. Oneway slab is more $35 \%$ extravagant in concrete beam. Meantime, for the rebar, oneway slab is more 10\% than twoway slab.

Keywords: Oneway slab, twoway slab, flexible structure

\section{PENDAHULUAN}

Menurut William A. Shrode dan Paul Davidov, "Perencanaan adalah suatu metode atau tolak ukur dalam melakukan dan menetapkan tindakan di lapangan." Suatu perencanaan bangunan harus direncanakan dengan mementingkan segi struktural bangunan, dimana setiap komponen struktur mampu bekerja menahan beban. Tidak hanya hal itu, segi arsitektural juga perlu diperhitungkan untuk mendukung kenyamanan pengguna bangunan. 
Bangunan gedung sekolah secara ruang lingkup pendidikan disesuaikan dengan asumsi normal jumlah siswa per kelas. Ukuran ruangan belajar perlu disesuaikan dengan jumlah siswa karena akan memengaruhi suasana kegiatan belajar mengajar. Fasilitas dan kenyamanan tempat belajar menjadi salah satu faktor terciptanya pendidikan yang berkualitas. Mengenai kekuatan struktur, komponen seperti kolom, balok, dan pelat, masing-masing diperlukan analisa struktur pembebanan dan dimensi yang akurat. Struktur merupakan sarana untuk menyalurkan beban dan akibat penggunaan atau kehadiran bangunan ke dalam tanah. Pemilihan kualitas material yang tepat diperlukan untuk membuat struktur, seperti persentase agregat, pasir, dan semen, jenis pembesian serta ukuran penampang. Sehingga secara keseluruhan perlu dihitung dan dianalisis untuk membuat suatu bangunan yang kuat dari segi struktural.

Salah satu komponen struktur dalam menahan beban adalah pelat. Secara geometri, penerapan pelat dibagi menjadi dua yaitu sistem pelat satu arah (One Way Slab) dan pelat dua arah (Two Way Slab). Perbedaannya terletak pada ukuran bentang penampang. Dikatakan satu arah jika rasio antara bentang terpanjang dan terpendek adalah lebih dari dua. Dan dikatakan dua arah jika rasio antara bentang terpanjang dan terpendek adalah kurang dari dua. Pada penelitian ini terkaji perbedaan perilaku struktur dan anggaran biaya antara sistem pelat satu arah dan dua arah pada bangunan sekolah dua lantai.

\section{METODE PENELITIAN}

Dalam perencanaan bangunan sekolah ini digunakan data sekunder berupa gambar denah, gambar tampak, gambar potongan, ukuran rencana komponen struktur, model pelat, daftar harga satuan material, daftar upah pekerja, dan analisa harga satuan pekerjaan. Berdasarkan data sekunder tersebut dilakukan perancangan struktur untuk kedua tipe pelat. Untuk menganalisis gaya dalam dilakukan dengan metode desain ultimit.

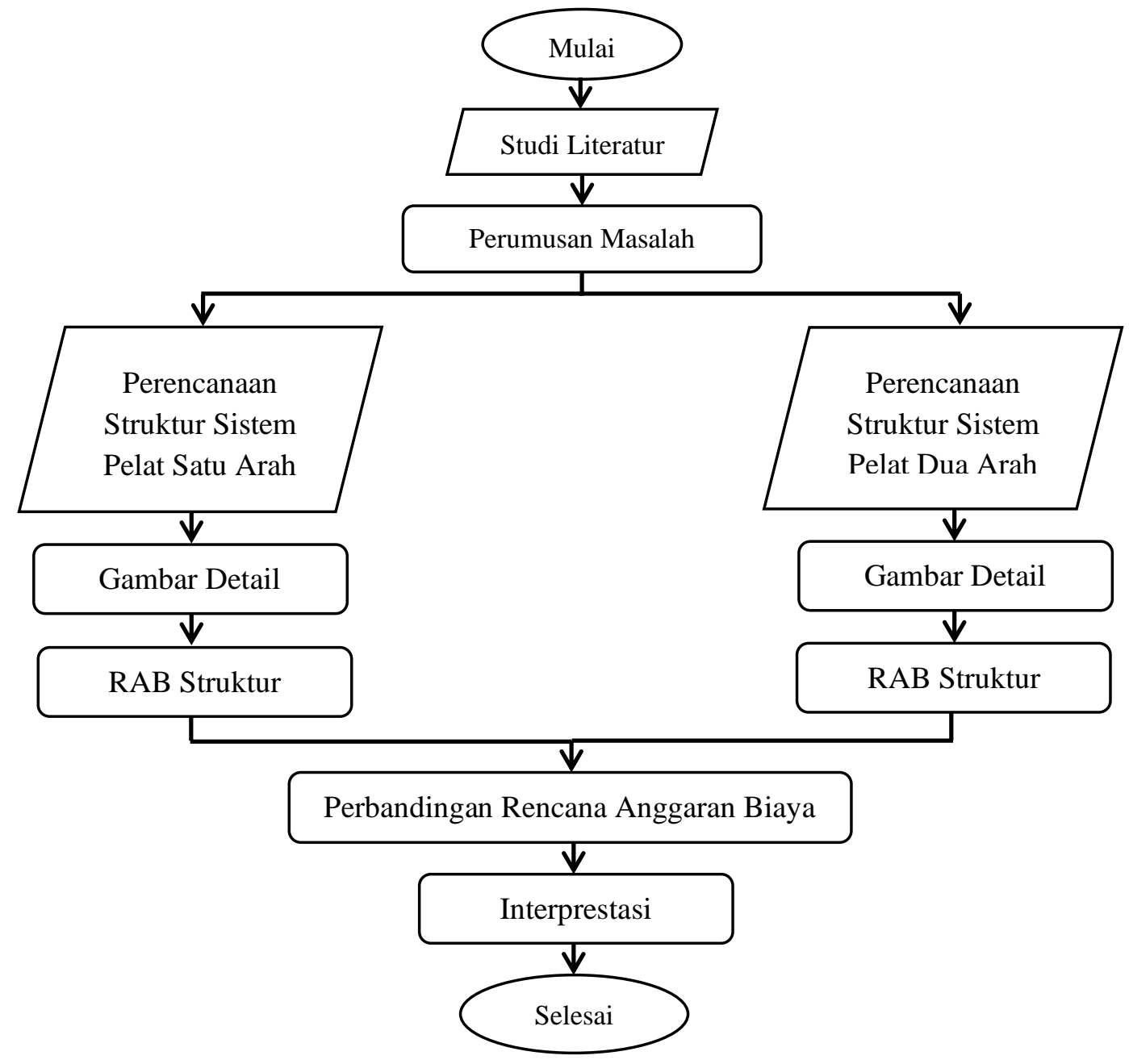




\section{DESAIN DAN ANALISIS}

Mutu kuat tekan beton yang digunakan sebesar 20 MPa dengan mutu baja tulangan $400 \mathrm{MPa}$. Dengan jumlah beban yang sama dibuat model pelat satu arah tipe A dan tipe B, dan model pelat dua arah tipe A dan tipe B. Objek berupa potongan kelas berukuran 9x8 $\mathrm{m}$.

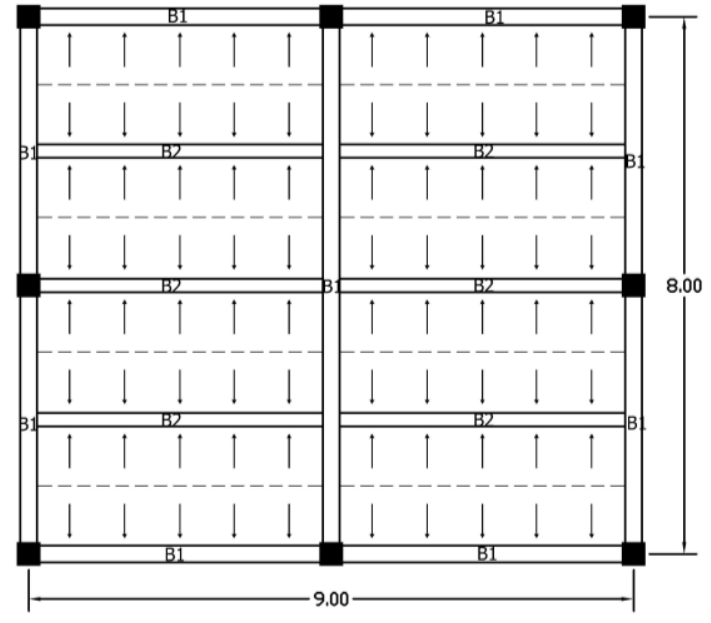

Gambar 1 Model pelat satu arah tipe A

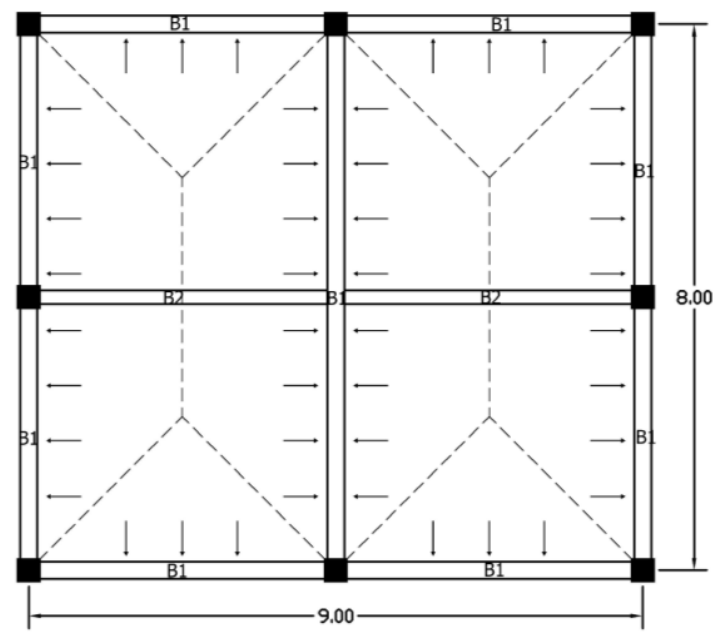

Gambar 4 Model pelat dua arah tipe A

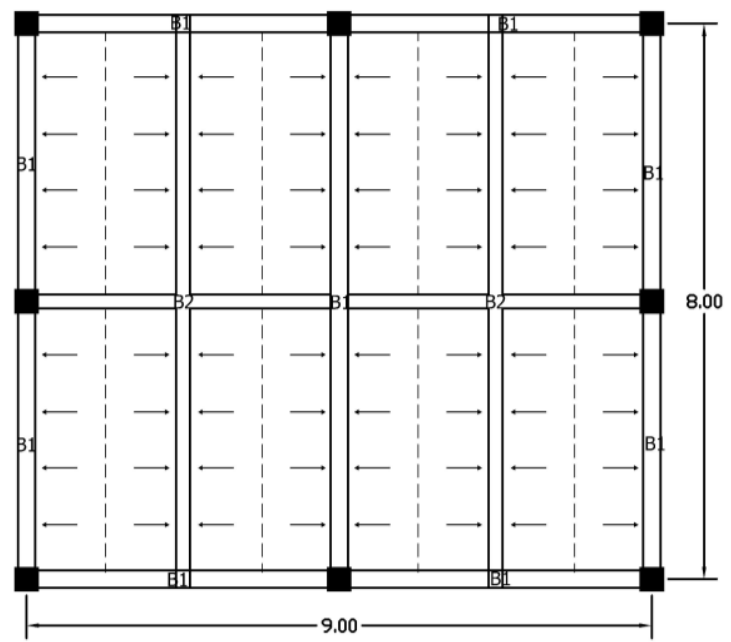

Gambar 2 Model pelat satu arah tipe B

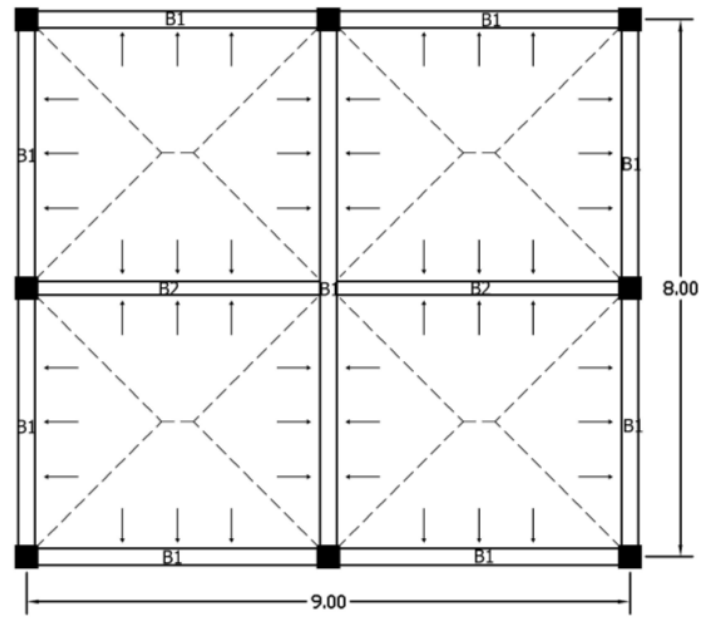

Gambar 5 Model pelat dua arah tipe B

Pada perencanaan ini beban yang didistribusikan ke balok dirincikan:

- Beban hidup lantai

- Beban mati pelat

- Beban dinding

$$
\begin{aligned}
& =250 \mathrm{~kg} / \mathrm{m}^{2} \\
& =339 \mathrm{~kg} / \mathrm{m}^{2} \\
& =250 \mathrm{~kg} / \mathrm{m}^{2}
\end{aligned}
$$

Kombinasi Pembebanan SNI 1727:2013

$\mathrm{U}=1,2 \mathrm{D}+1,6 \mathrm{DL}$

$\mathrm{U}=1,2 \mathrm{D}+1,6 \mathrm{DL}+0,5 \mathrm{R}$

$\mathrm{U}=1,2 \mathrm{D}+1,6 \mathrm{DL}+0,5 \mathrm{~W}$ 
Analisa gaya dalam (momen, geser, dan aksial) dilakukan pada ke empat model. Hasil reaksi gaya antar kedua sistem dilakukan perbandingan dari sisi efisiensi reaksi gaya. Diambil nilai terkecil antara model A dan B dari setiap sistem. Hasil menunjukkan bahwa sistem pelat satu arah tipe B dan sistem pelat dua arah tipe A yang sesuai kriteria efisiensi reaksi gaya dalam.

Tabel 1 Reaksi Gaya Sistem Pelat Satu Arah Tipe B

\begin{tabular}{cccccc}
\hline $\begin{array}{c}\text { Profil } \\
\text { Penampang } \\
(\mathrm{cm})\end{array}$ & $\begin{array}{c}\text { Momen } \\
\text { tumpuan } \\
\text { negatif } \\
(\mathrm{kNm})\end{array}$ & $\begin{array}{c}\text { Momen } \\
\text { tumpuan } \\
\text { positif } \\
(\mathrm{kNm})\end{array}$ & $\begin{array}{c}\text { Momen } \\
\text { Lapangan } \\
(\mathrm{kNm})\end{array}$ & $\begin{array}{c}\text { Shear } \\
(\mathrm{kN})\end{array}$ & $\begin{array}{c}\text { Axial } \\
(\mathrm{kN})\end{array}$ \\
\hline B1 $(25 \times 50)$ & -130.214 & 65.107 & 130.668 & -92.753 & 6.031 \\
B2 $(20 \times 30)$ & -57.429 & 28.7145 & 29.125 & -57.29 & -5.175 \\
B3 $(15 \times 25)$ & -20.325 & 10.1625 & 10.944 & -28.752 & -60.94 \\
Sloof $(20 \times 25)$ & -22.506 & 11.253 & 10.934 & -29.832 & -4.144 \\
Kolom $(35 \times 35)$ & & -42.131 & & -12.353 & -465.612 \\
\hline
\end{tabular}

Tabel 2 Reaksi Gaya Sistem Pelat Dua Arah Tipe A

\begin{tabular}{cccccc}
\hline $\begin{array}{c}\text { Profil } \\
\text { Penampang }\end{array}$ & $\begin{array}{c}\text { Momen } \\
\text { tumpuan } \\
\text { negatif } \\
(\mathrm{kNm})\end{array}$ & $\begin{array}{c}\text { Momen } \\
\text { tumpuan } \\
\text { positif } \\
(\mathrm{kNm})\end{array}$ & $\begin{array}{c}\text { Momen } \\
\text { Lapangan } \\
(\mathrm{kNm})\end{array}$ & $\begin{array}{c}\text { Shear } \\
(\mathrm{kN})\end{array}$ & $\begin{array}{c}\text { Axial } \\
(\mathrm{kN})\end{array}$ \\
\hline B1 $(25 \times 50)$ & -163.486 & 81.743 & 112.976 & -114.324 & 6.004 \\
B2 $(20 \times 30)$ & -41.688 & 20.844 & 26.816 & -34.957 & -10.348 \\
B3 (15x25) & -20.289 & 10.1445 & 11.013 & -28.746 & -63.867 \\
Sloof $(20 \times 25)$ & -22.606 & 11.303 & 10.987 & -29.84 & -3.694 \\
Kolom $(35 \times 35)$ & & -47.64 & & -15.096 & -540.737 \\
\hline
\end{tabular}

\section{HASIL PENELITIAN}

\section{A. Analisa Penampang}

1. Perhitungan tulangan lentur

Tumpuan balok Induk sistem pelat satu arah

Data penampang balok:
$\mathrm{f}^{\prime} \mathrm{c}=20 \mathrm{Mpa}$
$\mathrm{b}=250 \mathrm{~mm}$
fy $\quad=400 \mathrm{Mpa}$
$\mathrm{h}=500 \mathrm{~mm}$
$\varnothing \quad=0,8$
$\mathrm{s} \quad=40 \mathrm{~mm}$
$\beta_{1} \quad=0,85$

Direncanakan menggunakan tulangan D19 dengan dua lapis tulangan. Sengkang D10. Maka tinggi efektif balok,

$$
\begin{aligned}
& \mathrm{d}=500-(40+10+19+20)=411 \mathrm{~mm} \\
& M u=-130,214 \mathrm{kNm} . \\
& M n=\frac{M u}{\emptyset}=\frac{130,214}{0.8}=162,767 \mathrm{kNm}
\end{aligned}
$$

Koefisien tahanan, $R n=\frac{M n}{b . d^{2}}=\frac{162,767}{250 \cdot 411^{2}} \cdot 10^{6}=3,854$ 
Rasio tulangan, $\rho=\frac{0,85 f^{\prime}{ }_{c}}{f_{y}}\left(1-\sqrt{1-\frac{2 R n}{0,85 \cdot f^{\prime}{ }_{c}}}\right)$

$\rho=\frac{0,85 \cdot 20}{400}\left(1-\sqrt{1-\frac{2 \cdot 3,854}{0,85 \cdot 20}}\right)=0,0111$

Rasio tulangan minimum, $\rho_{\min }=\frac{\sqrt{f^{\prime} c}}{4 f_{y}}=\frac{\sqrt{20}}{4.400}=0,0028$

$\rho_{\text {min }}=\frac{1,4}{f_{y}}=\frac{1,4}{400}=0,0035$

Rasio tulangan maksimum, $\rho_{\text {maks }}=0,025$

$$
\begin{aligned}
& \rho_{\text {maks }}=0,75\left(\frac{0,85 \cdot f^{\prime}{ }_{c} \cdot \beta_{1}}{f_{y}} \cdot \frac{600}{600+f_{y}}\right) \\
& =0,75\left(\frac{0,85.20 .0,85}{400} \cdot \frac{600}{600+400}\right)=0,01625
\end{aligned}
$$

Karena $\rho_{\min }<\rho<\rho_{\text {maks }}$, maka digunakan $\rho=0,0111$

$A_{s}=\rho . b . d=0,0111.250 .411=1138 \mathrm{~mm}^{2}$

Luas tulangan minimum pada struktur lentur SNI 03-2847-2002 pasal 12.5(1):

$A_{s \min }=\frac{\sqrt{f^{\prime}}}{4 f_{y}} \cdot b_{w} \cdot d=\frac{\sqrt{20}}{4.400} \cdot 250.411=285 \mathrm{~mm}^{2}$

$A_{s \min }=\frac{1,4}{f_{y}} \cdot b_{w} \cdot d=\frac{1,4}{400} \cdot 250 \cdot 411=357 \mathrm{~mm}^{2}$

$A_{s \min }<A_{s}$, maka dipakai $A_{s}=1138 \mathrm{~mm}^{2}$.

Digunakan 6D16 $\left(A_{s}=1206 \mathrm{~mm}^{2}\right)$.

Rasio tulangan baru, $\rho=\frac{A_{s}}{b . d}=\frac{1206}{250.411}=0,0117$

2. Perhitungan tulangan geser

$$
\begin{aligned}
& V_{u}=-92,753 \mathrm{kN} \\
& V_{c}=\frac{1}{6} \cdot \sqrt{f^{\prime}} \cdot b \cdot d=\frac{1}{6} \cdot \sqrt{20} \cdot 250 \cdot 411=76,585 \mathrm{kN} \\
& \varnothing V_{c}=0,6 \cdot 76,585=45,951 \mathrm{kN} \\
& 3 \emptyset V_{c}=3.45,951=137,853 \mathrm{kN}
\end{aligned}
$$

Karena $\emptyset V_{c}<V_{u}<3 \emptyset V_{c}$, maka diperlukan tulangan geser.

$\emptyset V_{s}=V_{u}-\emptyset V_{c}=92,753-45,951=46,802 \mathrm{kN}$

$V_{s \text { perlu }}=\frac{\emptyset V_{s}}{\emptyset}=\frac{46,802}{0,6}=78 \mathrm{kN}$

Digunakan sengkang D10 $\left(\mathrm{A}_{\mathrm{v}}=157 \mathrm{~mm}^{2}\right)$

$s=\frac{A_{v} \cdot f_{y} \cdot d}{V_{s}}=\frac{157 \cdot 400 \cdot 411}{78000}=331 \mathrm{~mm}$

Batas spasi tulangan geser tidak boleh melebihi d/2 (SNI pasal 13.5.4.1)

$\frac{d}{2}=\frac{411}{2}=205,5 \mathrm{~mm}$, maka dipakai $200 \mathrm{~mm}$.

$V_{s}=\frac{A_{v} \cdot f_{y} \cdot d}{s}=\frac{157 \cdot 400 \cdot 411}{200}=129,054 \mathrm{kN}$

$V_{s \text { ada }}>V_{\text {s perlu, }}$, aman. 
Dengan perhitungan yang sama, untuk mencari kebutuhan tulangan struktur lentur, didapat rekapitulasi hasil tulangan balok induk dan balok anak dari kedua sistem geometri pelat. Gambar dan tabel menunjukkan kebutuhan tulangan pada komponen struktur lentur.

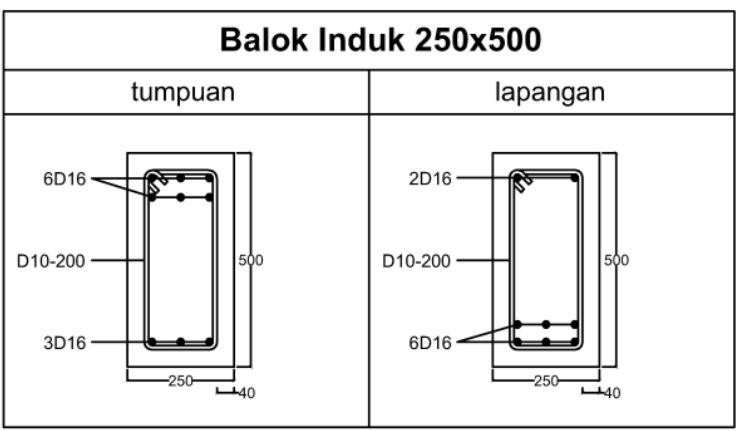

Gambar 6 Detail balok induk sistem pelat satu arah

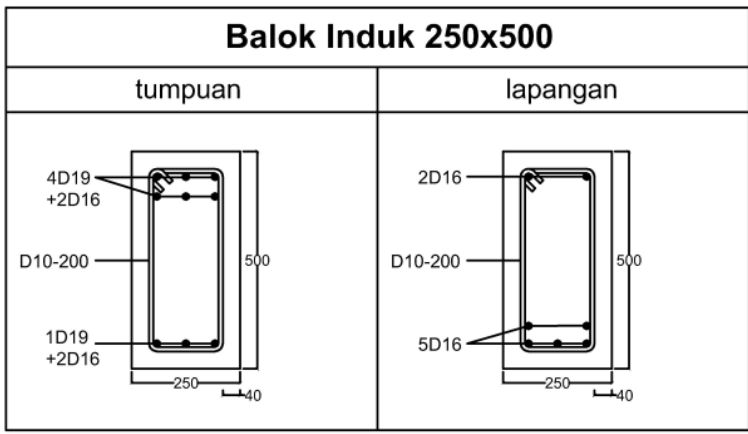

Gambar 8 Detail balok induk sistem pelat dua arah

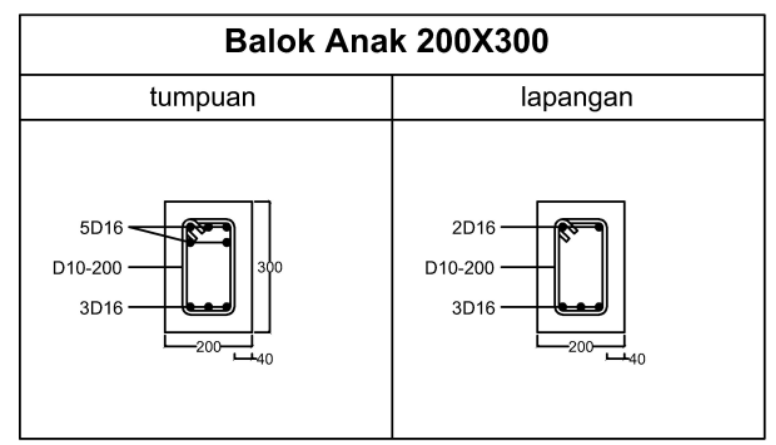

Gambar 7 Detail balok anak sistem pelat satu arah

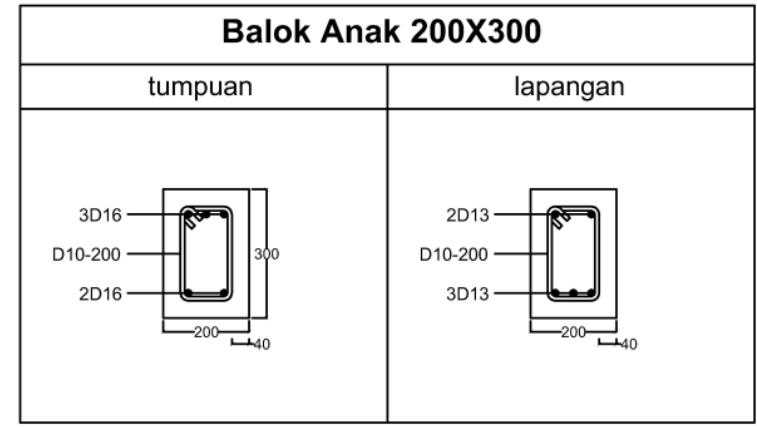

Gambar 9 Detail balok anak sistem pelat dua arah

Tabel 3. Kebutuhan tulangan struktur lentur sistem pelat satu arah

\begin{tabular}{|c|c|c|c|c|c|c|}
\hline \multirow[b]{2}{*}{ Tipe (cm) } & \multicolumn{3}{|c|}{ Tumpuan negatif } & \multicolumn{3}{|c|}{ Tumpuan positif } \\
\hline & $\begin{array}{c}\mathrm{M}_{\mathrm{u}} \\
(\mathrm{kNm})\end{array}$ & $\begin{array}{c}\mathrm{A}_{\mathrm{s}} \\
\left(\mathrm{mm}^{2}\right)\end{array}$ & $\mathrm{D} \quad(\mathrm{mm})$ & $\begin{array}{c}\mathrm{M}_{\mathrm{u}} \\
(\mathrm{kNm})\end{array}$ & $\begin{array}{c}\mathrm{A}_{\mathrm{s}} \\
\left(\mathrm{mm}^{2}\right)\end{array}$ & $\begin{array}{c}\mathrm{D} \\
(\mathrm{mm})\end{array}$ \\
\hline B1 $25 \times 50$ & -130.214 & 1138 & $6 \mathrm{D} 16$ & 65.107 & 527 & 3D16 \\
\hline B2 20x30 & -57.429 & 970 & $5 \mathrm{D} 16$ & 28.7145 & 412 & 3D16 \\
\hline B3 $15 \times 25$ & -20.325 & 435 & $4 \varnothing 12$ & 10.1625 & 193 & $2 \not 12$ \\
\hline
\end{tabular}

Tabel 4. Kebutuhan sengkang struktur lentur sistem pelat satu arah

\begin{tabular}{cccccccc}
\hline & \multicolumn{3}{c}{ Lapangan } & \multicolumn{5}{c}{ Sengkang } \\
Tipe (cm) & $\mathrm{M}_{\mathrm{u}}$ & $\mathrm{A}_{\mathrm{s}}$ & $\mathrm{D}$ & $\mathrm{V}_{\mathrm{u}}(\mathrm{kN})$ & $\mathrm{V}_{\mathrm{s}}$ & $\mathrm{D}_{\mathrm{v}}$ & $\mathrm{s}$ \\
& $(\mathrm{kNm})$ & $\left(\mathrm{mm}^{2}\right)$ & $(\mathrm{mm})$ & $(\mathrm{mm})$ & $(\mathrm{mm})$ \\
\hline B1 25x50 & 130.668 & 1138 & $6 \mathrm{D} 16$ & -92.753 & 78.00 & $\mathrm{D} 10$ & 200 \\
B2 20x30 & 29.125 & 419 & $3 \mathrm{D} 16$ & -57.29 & 59.41 & $\mathrm{D} 10$ & 120 \\
B3 15x25 & 10.944 & 209 & $2 \varnothing 12$ & -28.752 & 24.89 & $\varnothing 8$ & 100 \\
\hline
\end{tabular}


Tabel 5. Kebutuhan tulangan struktur lentur sistem pelat dua arah

\begin{tabular}{ccccccc}
\hline Tipe & \multicolumn{3}{c}{ Tumpuan negatif } & \multicolumn{3}{c}{ Tumpuan positif } \\
& $\begin{array}{c}\mathrm{M}_{\mathrm{u}} \\
(\mathrm{kNm})\end{array}$ & $\begin{array}{c}\mathrm{A}_{\mathrm{s}} \\
\left(\mathrm{mm}^{2}\right)\end{array}$ & $\begin{array}{c}\mathrm{D} \\
(\mathrm{mm})\end{array}$ & $\begin{array}{c}\mathrm{M}_{\mathrm{u}} \\
(\mathrm{kNm})\end{array}$ & $\begin{array}{c}\mathrm{A}_{\mathrm{s}} \\
\left(\mathrm{mm}^{2}\right)\end{array}$ & $\begin{array}{c}\mathrm{D} \\
(\mathrm{mm})\end{array}$ \\
\hline B1 25x50 & -163.486 & 1500 & $4 \mathrm{D} 19+2 \mathrm{D} 16$ & 81.74 & 673 & 1D19+2D16 \\
B2 20x30 & -41.688 & 637 & 3D16 & 20.84 & 289 & 2D16 \\
B3 15x25 & -20.289 & 434 & $4 \varnothing 12$ & 10.14 & 192 & $2 \varnothing 12$ \\
\hline
\end{tabular}

Tabel 6. Kebutuhan sengkang struktur lentur sistem pelat satu arah

\begin{tabular}{cccccccc}
\hline & \multicolumn{3}{c}{ Lapangan } & \multicolumn{3}{c}{ Sengkang } \\
Tipe & $\begin{array}{c}\mathrm{M}_{\mathrm{u}} \\
(\mathrm{kNm})\end{array}$ & $\begin{array}{c}\mathrm{A}_{\mathrm{s}} \\
\left(\mathrm{mm}^{2}\right)\end{array}$ & $\begin{array}{c}\mathrm{D} \\
(\mathrm{mm})\end{array}$ & $\begin{array}{c}\mathrm{V}_{\mathrm{u}} \\
(\mathrm{kN})\end{array}$ & $\begin{array}{c}\mathrm{V}_{\mathrm{s}} \\
(\mathrm{kN})\end{array}$ & $\begin{array}{c}\mathrm{D}_{\mathrm{v}} \\
(\mathrm{mm})\end{array}$ & $\begin{array}{c}\mathrm{s} \\
(\mathrm{mm})\end{array}$ \\
\hline B1 25x50 & 112.976 & 959 & $5 \mathrm{D} 16$ & -114.324 & 113.96 & $\mathrm{D} 10$ & 200 \\
B2 20x30 & 26.816 & 382 & $3 \mathrm{D} 13$ & -34.957 & 22.19 & $\mathrm{D} 10$ & 120 \\
B3 15x25 & 11.013 & 210 & $2 \varnothing 12$ & -28.746 & 24.88 & $\varnothing 8$ & 100 \\
\hline
\end{tabular}

\section{A. Rencana Anggaran Biaya}

Rekapitulasi anggaran biaya didapat dari hasil analisa satuan pekerjaan dan volume pekerjaan. Dalam pekerjaan balok induk ukuran $25 \times 50 \mathrm{~cm}$ didapat perhitungan:

Volume pekerjaan x Harga satuan pekerjaan $35.875 \mathrm{~m}^{3}$ x Rp. 4,124,100.00 = Rp. 147,952,087.50

Dengan pola perhitungan yang sama, didapat tabel keseluruhan rencana anggana biaya sistem pelat satu arah dan dua arah.

Tabel 7. Kebutuhan sengkang struktur lentur sistem pelat satu arah

\begin{tabular}{|c|c|c|c|c|c|}
\hline NO & URAIAN PEKERJAAN & VOL. & SAT. & $\begin{array}{c}\text { HARGA } \\
\text { SATUAN }\end{array}$ & JUMLAH HARGA \\
\hline I & SISTEM PELAT SATU ARAH & & & & \\
\hline 1 & Pek. Balok Induk 25/50 & 35.875 & $\mathrm{~m} 3$ & $\mathrm{Rp} \quad 4,058,100$ & Rp $145,584,338$ \\
\hline 2 & Pek. Balok Anak 20/30 & 14.46 & $\mathrm{~m} 3$ & $\mathrm{Rp} \quad 5,192,100$ & Rp $\quad 75,077,766$ \\
\hline 3 & Pek. Ring Balok 15/25 & 13.5 & $\mathrm{~m} 3$ & $\operatorname{Rp} 4,868,100$ & Rp $\quad 65,719,350$ \\
\hline 4 & Pek. Pelat Lantai Bondeck & 63 & $\mathrm{~m} 3$ & Rp $3,407,900$ & Rp $214,697,700$ \\
\hline 5 & Pek. Kolom 35/35 & 52.92 & $\mathrm{~m} 3$ & Rp $5,507,400$ & Rp 291,451,608 \\
\hline \multirow[t]{2}{*}{6} & Pek. Sloof 20/25 & 10.1 & $\mathrm{~m} 3$ & $\operatorname{Rp} 3,122,100$ & $\mathrm{Rp} \quad 31,533,210$ \\
\hline & Jumlah Pekerjaan I & & & & Rp $824,063,972$ \\
\hline II & SISTEMPELAT DUA ARAH & & & & \\
\hline 1 & Pek. Balok Induk 25/50 & 35.875 & $\mathrm{~m} 3$ & $\mathrm{Rp} \quad 4,184,100$ & Rp $150,104,588$ \\
\hline 2 & Pek. Balok Anak 20/30 & 7.02 & $\mathrm{~m} 3$ & $\mathrm{Rp} \quad 4,562,100$ & Rp $32,025,942$ \\
\hline 3 & Pek. Ring Balok 15/25 & 13.5 & $\mathrm{~m} 3$ & $\operatorname{Rp} 4,868,100$ & $\operatorname{Rp} \quad 65,719,350$ \\
\hline 4 & Pek. Pelat Lantai Bondeck & 63 & $\mathrm{~m} 3$ & $\mathrm{Rp} \quad 3,407,900$ & Rp 214,697,700 \\
\hline 5 & Pek. Kolom 35/35 & 52.92 & $\mathrm{~m} 3$ & $\operatorname{Rp} 5,507,400$ & Rp 291,451,608 \\
\hline \multirow[t]{3}{*}{6} & Pek. Sloof 20/25 & 10.1 & $\mathrm{~m} 3$ & $\mathrm{Rp} \quad 3,122,100$ & $\mathrm{Rp} \quad 31,533,210$ \\
\hline & Jumlah Pekerjaan II & & & & Rp 785,532,398 \\
\hline & Selisih Pekerjaan I dan II & & & & $\mathrm{Rp} \quad 38,531,574$ \\
\hline
\end{tabular}

Didapat anggaran biaya pekerjaan struktur untuk sistem pelat satu arah Rp. 836,594,401.50. Sedangkan sistem pelat dua arah Rp. 797,571,787.50. Dari kedua sistem tersebut menghasilkan selisih Rp. 39,022,614.00. 


\section{KESIMPULAN}

Setelah melakukan penelitian terhadap sistem pelat satu arah dan dua arah pada bangunan gedung sekolah dua lantai, maka penulis dapat mengambil kesimpulan sebagai berikut:

1. Perilaku struktur gedung antara sistem pelat satu arah dan dua arah memiliki kesamaan pada komponenkomponen struktur, kecuali balok induk dan balok anak. Dengan ukuran dimensi dan jenis beban yang sama, sistem pelat satu arah pada balok induk menghasilkan momen tumpuan $-130,214 \mathrm{kNm}$, dan balok anak $-57,429 \mathrm{kNm}$. Sedangkan sistem pelat dua arah pada balok induk menghasilkan momen tumpuan $-163,486 \mathrm{kNm}$, dan balok anak $-41,688 \mathrm{kNm}$.

2. Luas tulangan perlu balok induk daerah tumpuan pada sistem pelat satu arah $1138 \mathrm{~mm}^{2}$, dan balok anak $970 \mathrm{~mm}^{2}$. Sedangkan luas tulangan perlu balok induk daerah tumpuan pada sistem pelat dua arah 1500 $\mathrm{mm}^{2}$, dan balok anak $637 \mathrm{~mm}^{2}$.

3. Rencana anggaran biaya pekerjaan struktur sistem pelat satu arah senilai Rp 824,063,971 sedangkan pekerjaan struktur sistem pelat dua arah senilai Rp. 785,532,397 dengan selisih Rp. 38,531,574. Hal ini menunjukkan bahwa sistem pelat dua arah lebih efisien dari segi biaya dibandingkan dengan sistem pelat satu arah.

\section{DAFTAR PUSTAKA}

Asroni, H Ali. 2010. Balok dan Pelat Beton Bertulang. Yogyakarta: Graha Ilmu.

Badan Standarisasi Nasional. 2002. Tata Cara Perencanaan Struktur Beton Untuk Bangunan Gedung. SNI 032847-2002. Yayasan LPMB Bandung.

Departemen Pekerjaan Umum. 1983. Peraturan Pembebanan Indonesia untuk Gedung. Yayasan LPMB Bandung.

Dipohusodo, Istimawan. 1994. Struktur Beton Bertulang. Jakarta: PT. Gramedia Pustaka Utama.

Fahri, Muhammad., Suyadi., dan Purwanto, Edy. 2016. Tinjauan Momen Lentur Pelat Dua Arah dengan Metode Perencanaan Langsung dan Metode Elemen Hingga. Lampung: Universitas Lampung.

Imran, Iswandi., dan Hendrik, Fajar. 2014. Perencanaan Dasar Struktur Beton Bertulang. Bandung: Penerbit ITB.

Imran, Iswandi., dan Hendrik, Fajar. 2016. Perencanaan Lanjut Struktur Beton Bertulang. Bandung: Penerbit ITB.

Kriswanto, Dikyipan. 2015. Perencanaan Struktur Pelat Beton Bertulang untuk Rumah Tinggal. Semarang: Universitas Negeri Semarang.

L. Wahyudi. Rahim, Syahril A. 1997. Struktur Beton Bertulang Standar Baru SNI T-15-1991-03. Jakarta: Gramedia.

McCormac, Jack C. 2003. Desain Beton Bertulang Edisi Kelima. Jakarta: Erlangga.

Nasution, Amrinsyah. 2009. Analisis dan Desain Struktur Beton Bertulang. Bandung: Penerbit ITB.

Sitohang, Hendri. 2008. Analisa Pelat Satu Arah (One Way Slab) dari Teori M. Levy. Sumatera: Universitas Sumatera Utara.

Syamsi, Muhammad Ibnu. 2015. Perbandingan Analisis Two Way Slab With Beam dengan Flat Slab. Yogyakarta: Universitas Muhammadiyah Yogyakarta.

Wahyuni, Tri. 2011. Perencanaan Struktur Gedung Sekolah 2 Lantai. Surakarta: Universitas Sebelas Maret 